\title{
Penerapan Augmented Reality pada Pengenalan Hewan Nokturnal
}

\author{
Budi Anandita Nugraha ${ }^{1}$, R.Reza El Akbar ${ }^{2}$, Rohmat Gunawan ${ }^{3}$ \\ ${ }^{1,2}$ Teknik Informatika, Fakultas Teknik, Universitas Siliwangi \\ E-mail: ${ }^{1}$ Budianann.bass@gmail.com, ${ }^{2}$ reza@unsil.ac.id, ${ }^{3}$ rohmatgunawan@unsil.ac.id
}

\begin{abstract}
Abstrak - Hewan nokturnal menarik untuk dipelajari karena mempunyai kemampuan untuk beradaptasi secara khusus terhadap lingkungannya. Beberapa kemampuan khusus yang dimiliki hewan nokturnal diantaranya : memiliki mata khusus yang dapat melihat dengan baik dalam kondisi gelap, mengeluarkan suara bernada tinggi yang memantul dari objek sebagai panduan ekolokasi. Eksplorasi mengenai hewan nokturnal hanya dapat dilakukan pada malam hari, sehingga tidak semua tingkatan usia manusia dapat dengan mudah melakukannya, terutama anak-anak. Oleh karena itu beberapa informasi mengenai hewan nokturnal masih terbatas. Untuk mengatasi masalah tersebut, dalam penelitian ini dibuat suatu media pembelajaran hewan nokturnal dengan memanfaatkan teknologi Augmented Reality (AR). Teknologi AR dipilih karena mampu membantu menstimulasi berfikir secara konseptual dan merasakan 3D, meningkatkan gambaran (representasi) dan persepsi, menciptakan suasana belajar yang interaktif dan atraktif serta lebih menyenangkan. Dari Hasil penelitian, telah dibangun suatu aplikasi pengenalan hewan nokturnal, dengan menerapkan teknologi AR. Terdapat 6 hewan nokturnal yang dapat diakses dengan menerapkan teknologi AR. Virtual button diterapkan pada aplikasi untuk mengaktifkan fungsi audio. Berdasarkan hasil percobaan pada penelitian, marker yang dibuat dapat diakses pada jarak 10-20 $\mathrm{cm}$, dengan sudut kemiringan antara $45^{\circ}-90^{\circ}$ serta tingkat occlusion sebesar $50 \%$.
\end{abstract}

Kata Kunci --Augmented Reality, Hewan, Nokturnal

\begin{abstract}
Nocturnal animals are interesting to learn because they have the ability to adapt specifically to their environment. Some special abilities that nocturnal animals have include: having special eyes that can see well in dark conditions, emitting high-pitched sounds that bounce off objects as a guide to echolocation. Exploration of nocturnal animals can only be done at night, so that not all levels of human age can easily do so, especially children. Therefore some information about nocturnal animals is still limited. To overcome this problem, in this study a media for learning nocturnal animals was made using Augmented Reality (AR) technology. AR technology was chosen because it can help stimulate conceptual thinking and feel 3D, improve image (representation) and perception, create an interactive and attractive learning atmosphere and more fun. From the results of the study, an application for nocturnal animal recognition has been built, by applying AR technology. There are 6 nocturnal animals that can be accessed by applying AR technology. Virtual button is applied to the application to activate the audio function. Based on experimental results in the study, markers made can be accessed at a distance of 10-20 cm, with a slope between 450-90 and occlusion rates of $50 \%$.
\end{abstract}

Keywords-Augmented Reality, Animal, Nocturnal

\section{PENDAHULUAN}

Hewan nokturnal merupakan istilah untuk jenis hewan yang lebih aktif di malam hari dari pada siang hari. Hewan-hewan ini tidur di siang hari, beberapa di dalam lubang atau sarang. Beberapa hewan gurun, aktif di malam hari untuk menghindari panas siang hari yang ekstrem. Hewan nokturnal menarik untuk dipelajari karena mempunyai kemampuan untuk beradaptasi secara khusus terhadap lingkungannya [4]. Beberapa hewan nokturnal seperti: burung hantu, lemur dan kucing, memiliki mata khusus yang dapat melihat dengan baik dalam kondisi gelap. Kelelawar, menggunakan ekolokasi, di mana hewan itu mengeluarkan suara bernada tinggi yang memantul dari 
objek; suara tersebut kemudian diterima oleh hewan, memberikan informasi tentang bentuk, arah, jarak, dan tekstur objek. Hewan nokturnal lainnya (seperti kelinci) memiliki pendengaran yang baik.

Eksplorasi mengenai hewan nokturnal hanya dapat dilakukan pada malam hari, sehingga tidak semua tingkatan usia manusia dapat dengan mudah melakukannya, terutama anak-anak. Oleh karena itu beberapa informasi mengenai hewan nokturnal masih terbatas. Untuk mengatasi masalah tersebut, dalam penelitian ini dibuat suatu media pembelajaran hewan nokturnal dengan memanfaatkan teknologi Augmented Reality (AR). Teknologi AR dipilih karena mampu membantu menstimulasi berfikir secara konseptual dan merasakan 3D, meningkatkan gambaran (representasi) dan persepsi, menciptakan suasana belajar yang interaktif dan atraktif serta lebih menyenangkan [6].

Penerapan teknologi AR dalam pengenalan hewan telah dilakukan pada penelitian sebelumnya diantaranya: Penggunaan fiduciary marker [7], single marker [2], markerless based [3]. Fiduciary marker diterapkan dalam penelitian tentang mengatasi phobia kecoa. Dalam pengujian penelitian, partisipan menggunakan kamera yang diletakan didekat mata. Kemudian kamera menscan marker yang dipegang partisipan sehingga muncul animasi kecoa. Lalu partisipan diminta untuk menilai tingkat kecemasan mereka (dari 0 hingga 10) pada 8 momen berbeda. Kekurangan teknik fiduciary marker adalah image yang digunakan hanya berupa kotak-kotak hitam putih yang sulit dalam pelacakan [7]. Single marker diterapkan dalam penelitian pengenalan hewan purbakala. Digunakan marker bergambar hewan purbakala yang kemudian discan oleh smartphone. Adapun kekurangan dari pengenalan penanda single marker yaitu tidak cukup stabil dalam memberikan informasi [2]. Markerless based diterapkan dalam penelitian pengenalan hewan berbasis AR. Hasil output implementasinya adalah aplikasi berbasis android pada smartphone. Adapun kekurangan metode ini adalah menggunakan banyak feature point sebagai penandanya, sehingga bila akan menampilkan objek virtual, feature point tersebut harus terdeteksi sepenuhnya oleh kamera. Jika tidak maka objek virtual yang dihasilkan akan tidak cukup baik [3].

Menurut riset Computer Technology Research (CTR) seseorang mampu mengingat 20\% dari yang dilihat, 30\% dari yang didengar, mengingat 50\% dari yang didengar dan dilihat. Maka dari itu Augmented reality sangat berpotensi dalam menarik, menginspirasi, dan memotivasi pelajar, untuk mengeksplorasi dan melakukan pengontrolan dari berbagai prespektif yang berbeda, yang sebelumnya tidak menjadi bahan pertimbangan dalam dunia pendidikan [9].

Berdasarkan masalah tersebut pada penelitian ini diterapkan teknologi AR berbasis marker dalam pengenalan hewan nokturnal. Virtual button ditambahkan untuk mengaktifkan fitur suara, fitur rotasi dan zoom ditambahkan pada saat menampilkan video. Pada tahap akhir penelitian dilakukan pengujian jarak, sudut kemiringan dan occulision pada marker terhadap kamera.

\section{METODE PENELITIAN}

Metode perancangan yang digunakan dalam penelitian ini menggunakan metode rekayasa perangkat lunak multimedia versi Luther-Sutopo. Metode Luther-Sutopo yang digunakan ditampilkan pada gambar 1 .

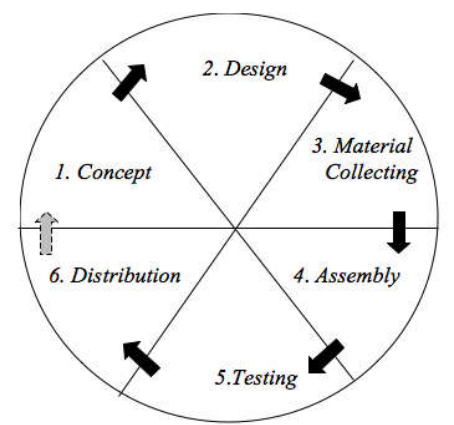

Gambar 1. Metode Luther-Sutopo [15]

\subsection{Concept}

Pada tahap pertama dilakukan literature review dari peneletian terdahulu untuk mengetahui perkembangan terkini dari topik penelitian terkait. Setelah semua data terkumpul, dilakukan analisa untuk menentukan pengguna (user) dan tujuan aplikasi, elemen multimedia seperti gambar, animasi, 
warna, suara, dan teks yang sesuai, rencana rancangan tampilan antarmuka, ukuran aplikasi, serta navigasi yang diperlukan oleh aplikasi. Hasil dari tahap ini ditampilkan pada tabel 1.

Tabel 1. Gambaran umum aplikasi pengenalan hewan nokturnal berbasis AR

\begin{tabular}{|c|c|}
\hline Judul & Augmented Reality Hewan Nokturnal \\
\hline Audiens & Anak sekolah. \\
\hline Durasi & Tidak terbatas (Unlimited) \\
\hline Image & $\begin{array}{l}\text { Format*.png, *.jpeg, *.gif dan gambar bertipe vector yang } \\
\text { dibuat sebagai image dan animasi }\end{array}$ \\
\hline Audio & Instrumen dengan format $*$.wav dan *.mp3 \\
\hline Animasi & $\begin{array}{l}\text { Animasi berbentuk } 3 \mathrm{~d} \text { yang dibuat menggunakan Blender } \\
3 \mathrm{~d}\end{array}$ \\
\hline Interaktifitas & $\begin{array}{ll}\text { - } & \text { Tombol Menu } \\
\text { - } & \text { Tomboluntukmengaktifkankameraaugmented reality. } \\
\text { - } & \text { Tomboluntukpemanggilansuara. } \\
\text { - } & \text { Tombol kuis } \\
\text { - } & \text { Tombol panduan } \\
\text { - } & \text { Tombol tentang } \\
\text { - } & \text { Tombolexit. }\end{array}$ \\
\hline
\end{tabular}

\subsection{Design}

Tahap perancangan merupakan tahap pembuatan spesifikasi mengenai arsitektur aplikasi, gaya, tampilan, dan kebutuhan atau bahan untuk aplikasi. Perancangan dari setiap scene dengan menggunakan storyboard dan penentuan tautan (link) dari satu scene ke scene yang lain dengan menggunakan struktur navigasi serta perancangan antarmuka.

\subsubsection{Storyboard}

Perancangan storyboard dari aplikasi yang dibuat menentukan gambaran dari scene, bentuk visual dan perancangan, audio, durasi, dan informasi. Hasil dari perancangan storyboard ini akan menjadi acuan dalam pembuatan tampilan pada tahap implementasi yang didalamnya terdapat keterangan scene, visual atau gambaran dari scene, tautan menuju ke scene tertentu, dan keterangan suara yang akan dimasukkan ke dalam aplikasi seperti pada tabel 2.

\begin{tabular}{ll} 
Scene splash & $\begin{array}{l}\text { Merupakan Scene pembuka darimedia pembelajaran, terdapat gambar } \\
\text { hewan. }\end{array}$ \\
\hline Sceneloading & Terdapat loading bar yang menunjukan media pembelajaran sedang memuat. \\
\hline $\begin{array}{l}\text { Scene } \\
\text { main_menu }\end{array}$ & $\begin{array}{l}\text { Terdapat background dan pilihan menu yaitu Game, Panduan, AR Camera, } \\
\text { Tentang dan Keluar. }\end{array}$ \\
\hline $\begin{array}{l}\text { Scene } \\
\text { panduan }\end{array}$ & Memuatinformasi bagaimana mengoprasikan media pembelajaran. \\
Scenetentang & Memuat informasi mengenai pembuat media pembelajaran. \\
\hline $\begin{array}{l}\text { Scene } \\
\text { ARcamera }\end{array}$ & Scene ini untuk menjalankan kamera dan memulai scan kartu. \\
\hline Scene Game & Scene 2 Beris Scene Scene untuk menjalankan system pada game. \\
\hline Scene soal1-10 & Soal game no 1-10 \\
\hline $\begin{array}{l}\text { Scene nilai 0- } \\
\text { 100 }\end{array}$ & Tampil nilai 0-100 \\
\hline
\end{tabular}




\subsubsection{Struktur Navigasi}

Struktur navigasi yang digunakan dalam perancangan produk multimedia ini adalah navigasi model hierarkis dimana pengguna melakukan navigasi di sepanjang cabang pohon struktur yang yang terbentuk seperti pada gambar 2 .

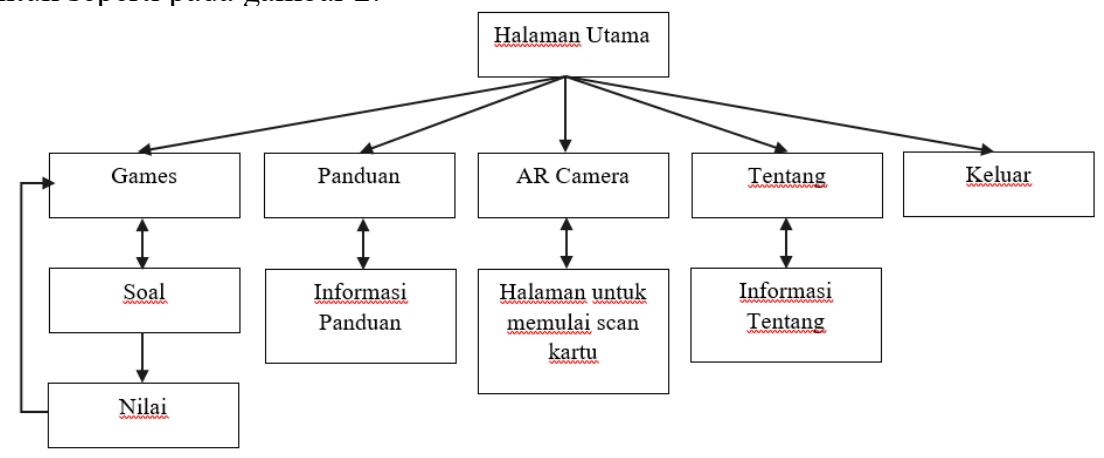

Gambar 2. Struktur Navigasi Hirarki

\subsection{Material Collecting}

Tahap selanjutnya adalah material collecting, yaitu pengumpulan bahan/materi yang akan ditampilkan pada media pembelajaran seperti teks, gambar, animasi, dan suara. Adapun metode dalam pengumpulan data adalah sebagai berikut :

\subsubsection{Studi Pustaka} dan e-Book:

Studi pustaka dilakukan dengan cara mengumpulkan data dari literatur review penelitian

a. Hewan Nokturnal dari e-Book: Roots, C. [14]. Nocturnal Animals (Greenwood Guides to the Animal World).

b. Media Pembelajaran dari jurnal: Turbn [16]. Pemahaman Media Pembelajaran Dalam Proses Belajar Mengajar

c. Multimedia dari jurnal: Vaughan, T. [17].Multimedia: Making It Work. 8th Edition.

d. Augmented Reality dari jurnal: Ivanova, M., \& Ivanov, G. [6]. Enhancement of Learning and Teaching in Computer Graphics Through Marker Augmented Reality Technology.

\subsubsection{Desain}

Pengumpulan bahan interface, model animasi dan marker dilakukan dengan cara mendesain diantaranya:

a. Desain icon dirancang menggunakan Adobe Photoshop CS5.

b. Desain background dirancang menggunakan Adobe Photoshop CS5.

c. Desain interfacesplash, mainmenu, panduan, tentang, kuis dirancang menggunakan Adobe Photoshop CS5.

d. Desain marker dirancang menggunakan Adobe Photoshop CS5.

e. Desain model animasi dirancang menggunakan Blender 3D.

f. Desain Animasi 3D dirancang menggunakan Unity 3D.

g. Suara dari situs : https://www.audioblocks.com/

\subsection{Assembly}

Pada tahap ini dilakukan pembuatan opening scene. Sesaat setelah opening scene muncul loading scene dan akan diarahkan ke scene main menu, secara otomatis akan dilakukan pemutaran audio sebagai background music (BGM) dari media pembelajaran. Kemudian pada scene main menu dilakukan pengisian dan penyesuaian letak objek yang diperlukan, seperti judul, background, serta tombol. 


\subsection{Testing}

Dalam pengujian alfa ini pengujian dilakukan tidak hanya setelah aplikasi selesai secara keseluruhan, tetapi dilakukan pada tiap scene atau dapat juga dilakukan pada proses assembly. Sedangkan untuk pengujian beta dilakukan pada satu atau lebih end-user pada sasaran pengguna aplikasi yang melibatkan 30 orang responden. Pengujian yang akan dilakukan terdiri dari beberapa bagian diantaranya adalah antarmuka (interface), cara pengoperasian, isi atau materi, manfaat dan pengembangan. Pengujian dilakukan dengan memberikan kuesioner kepada responden

\subsection{Distribtion}

Setelah program melalui tahapan testing dan selesai dibuat, selanjutnya dilakukan publikasi program menjadi format apk sehingga program siap dipasang pada perangkat Android. Pada tahapan pendistribusian ini aplikasi media pembelajaran akan diunggah ke Google Drive dan disebar melalui media sosial, untuk kartu bergambar khusus dapat di download melalui link yang disertakan di halaman panduan pada aplikasi.

\section{HASIL DAN PEMBAHASAN}

\subsection{Hasil dan Implementasi}

\subsubsection{Tampilan Menu}

Main menu adalah scene awal yang muncul pada saat program pertama kali dijalankan. Pada scene ini terdapat pilihan menu dan ketika di klik akan berpindah pada scene yang berbeda seperti pada gambar 3 .

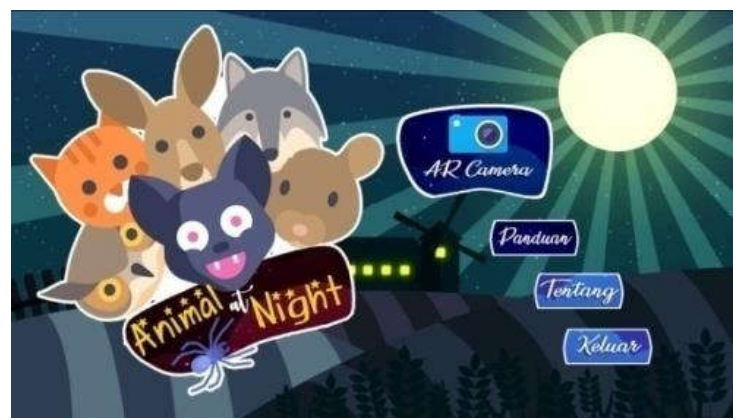

Gambar 3. Tampilan Scene Main menu

\subsubsection{Tampilan Game}

Pada scene ini user akan dihadapkan dengan pertanyaan berupa pilihan ganda dengan 4 opsi jawaban. Terdapat button X untuk keluar dari scene games dan kembali ke halaman utama seperti pada gambar 4 .

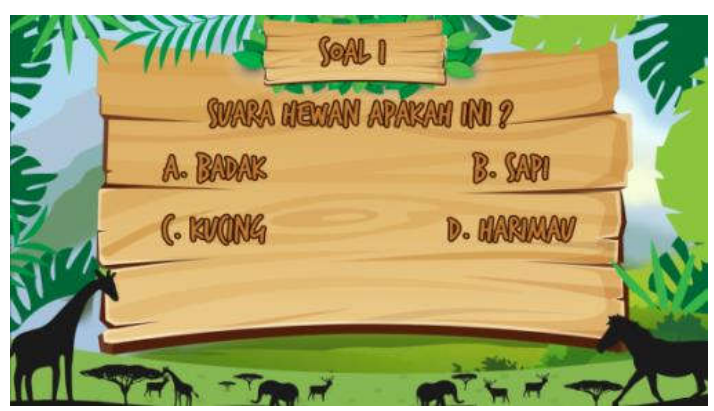

Gambar 4. Tampilan scenegames soal 


\subsubsection{Tampilan Panduan}

Pada tampilan panduan ini terdapat informasi cara menggunakan media pembelajaran, pada halama ini juga terdapat tombol kembali untuk kembali kehalaman utama seperti pada gambar 5 .

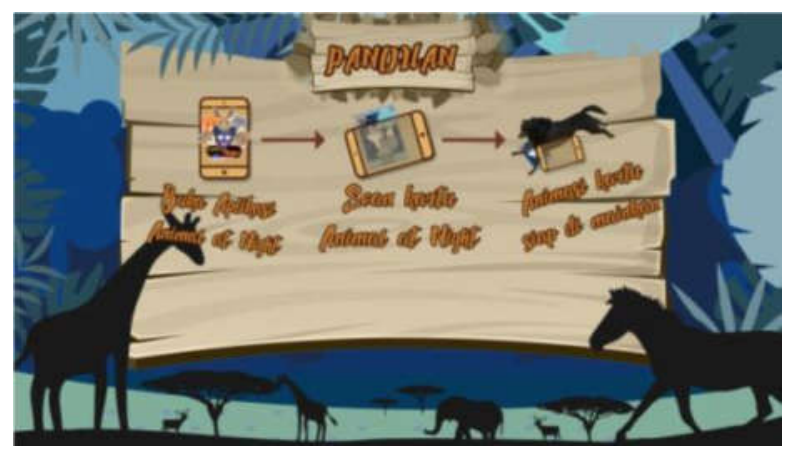

Gambar 5. Tampilan Panduan

\subsubsection{Tampilan AR Camera}

Dalam scene ini aplikasi media pembelajaran akan mengakses kamera ponsel yang digunakan untuk men-scan kartu khusus bergambar. Juga terdapat tombol kembali untuk keluar dari scene ini dan tombol speaker untuk menyuarakan suara hewan yang di scan seperti pada gambar 6 .

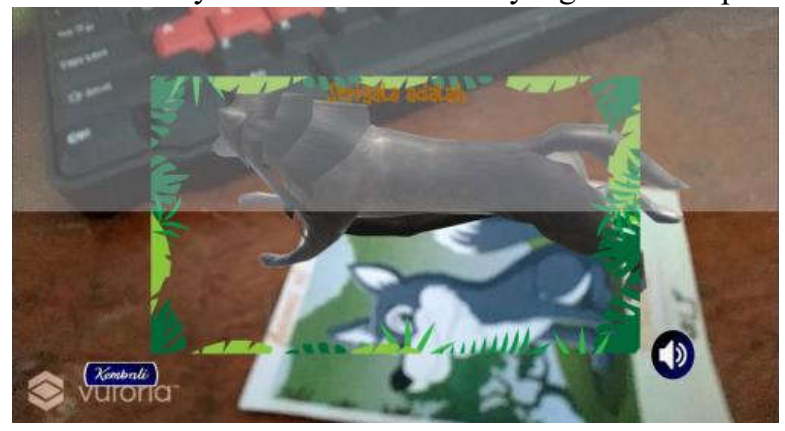

Gambar 6. Tampilan AR camera

\subsection{Hasil Pengujian}

\subsubsection{Pengujian Interface}

Tabel 3. Hasil Pengujian pada marker

\begin{tabular}{lll}
\hline Data Masukan & Hasil Pengamatan & Hasil Pengujian \\
\hline $\begin{array}{l}\text { Marker Burung } \\
\text { hantu }\end{array}$ & Menampilkan objek 3D burung hantu & {$[\sqrt{ }]$ Diterima [ ]Ditolak } \\
\hline Marker Tikus & Menampilkan objek 3D tikus & {$[\sqrt{ }]$ Diterima [ ]Ditolak } \\
\hline Marker Laba-laba & Menampilkan objek 3D laba-laba & {$[\sqrt{ }]$ Diterima [ ]Ditolak } \\
\hline Marker Kecoa & Menampilkan objek 3D kecoa & {$[\sqrt{ }]$ Diterima [ ]Ditolak } \\
\hline Marker Serigala & Menampilkan objek 3D serigala & {$[\sqrt{ }]$ Diterima [ ]Ditolak } \\
\hline Marker Kelelawar & Menampilkanobjek 3D Kelelawar & {$[\sqrt{ }$ Diterima [ ]Ditolak } \\
\hline
\end{tabular}


Tabel 4. Hasil Pengujian fungsi animasi hewan

\begin{tabular}{|c|c|c|}
\hline Data Masukan & HasilPengamatan & HasilPengujian \\
\hline $\begin{array}{l}\text { Marker Burung hantu dan } \\
\text { Objek 3D Burung hantu } \\
\text { yang sudah muncul }\end{array}$ & $\begin{array}{l}\text { Menampilkan animasi Burung hantu } \\
\text { dan suara burung hantu }\end{array}$ & $\begin{array}{l}{[\sqrt{ }] \text { Diterima }} \\
{[\text { ]Ditolak }}\end{array}$ \\
\hline $\begin{array}{l}\text { Marker Tikus dan Objek } \\
\text { 3D Tikus yang sudah } \\
\text { muncul }\end{array}$ & $\begin{array}{l}\text { Menampilkan animasi tikus dan suara } \\
\text { tikus }\end{array}$ & $\begin{array}{l}{[\sqrt{ }] \text { Diterima }} \\
{[\text { ]Ditolak }}\end{array}$ \\
\hline $\begin{array}{l}\text { Marker Laba-laba dan } \\
\text { Objek 3D Laba-laba yang } \\
\text { sudah muncul }\end{array}$ & $\begin{array}{l}\text { Menampilkan animasi laba-laba dan } \\
\text { suara laba-laba }\end{array}$ & $\begin{array}{l}{[\sqrt{ }] \text { Diterima }} \\
{[\text { Ditolak }}\end{array}$ \\
\hline $\begin{array}{l}\text { Marker Kecoa dan Objek } \\
\text { 3D Kecoa yang sudah } \\
\text { muncul }\end{array}$ & $\begin{array}{l}\text { Menampilkan animasi kecoa dan } \\
\text { suara kecoa }\end{array}$ & $\begin{array}{l}{[\sqrt{ }] \text { Diterima }} \\
{[\text { Ditolak }}\end{array}$ \\
\hline $\begin{array}{l}\text { Marker Serigala dan Objek } \\
\text { 3D Serigala yang sudah } \\
\text { muncul }\end{array}$ & $\begin{array}{l}\text { Menampilkan animasi serigala dan } \\
\text { suara serigala }\end{array}$ & $\begin{array}{l}{[\sqrt{ }] \text { Diterima }} \\
{[\text { Ditolak }}\end{array}$ \\
\hline $\begin{array}{l}\text { Marker Kelelawar dan } \\
\text { Objek 3D Serigala yang } \\
\text { sudah muncul }\end{array}$ & $\begin{array}{l}\text { Menampilkan animasi dan suara } \\
\text { kelelawar }\end{array}$ & $\begin{array}{l}{[\sqrt{ }] \text { Diterima }} \\
{[\text { Ditolak }}\end{array}$ \\
\hline
\end{tabular}

\subsubsection{Pengujian Jarak}

Pengujian untuk menentukan jarak deteksi minimum sehingga dapat menetapkan batas antara smartphone ke image target dalam proses pelacakan seperti pada Gambar 7. Pengujian dilakukan dengan meletakan smartphone pada jarak minimal terdekat untuk pendeteksian, kemudian mulai menjauh dari image target sampai tidak terdeteksi lagi. Terdapat 2 ukuran marker yang digunakan dalam pengujian dengan perbandingan skala 1:3. Hasil ini dapat dilihat pada Tabel 5 untuk ukuran $7 \times 10 \mathrm{~cm}$ dan tabel 6 untuk ukuran $21 \times 30 \mathrm{~cm}$.

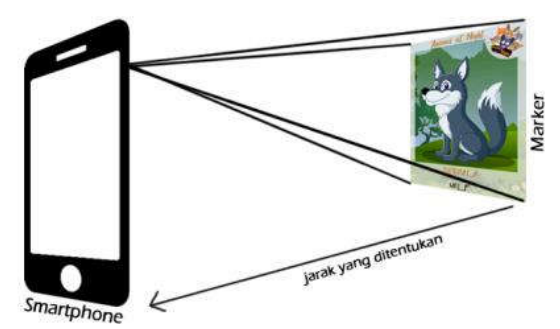

Gambar 7. Menentukan Jarak Pelacakan

\subsubsection{Pengujian Sudut}

Pengujian ini untuk menentukan sudut maksimum pada saat sedang melakukan pendeteksian image target. Seperti pada gambar 8 pengujian dimulai dari posisi objek terdeteksi pada sudut $90^{\circ}$ dan mulai menurun sampai tidak bisa melakukan pelacakan. Hasil ini dapat dilihat pada tabel 5 dan tabel 6.

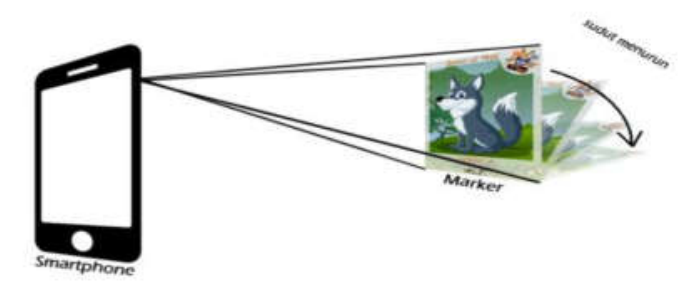

Gambar 8. Visualisasi menentukan sudut 
Tabel 5. Pengujian Jarak dan Sudut marker 7x10cm

\begin{tabular}{|c|c|c|c|c|c|}
\hline No & Data Masukan & Jarak & Sudut & Pengamatan & Hasil Pengujian \\
\hline 1. & Marker & $10 \mathrm{~cm}$ & $0^{\circ}$ & Tidak Muncul Objek 3D & $\begin{array}{l}{[] \text { Diterima }} \\
{[\sqrt{ }] \text { Ditolak }}\end{array}$ \\
\hline 2. & Marker & $20 \mathrm{~cm}$ & $0^{\circ}$ & Tidak Muncul Objek 3D & $\begin{array}{l}\text { [ ] Diterima } \\
{[\sqrt{ }] \text { Ditolak }}\end{array}$ \\
\hline 3. & Marker & $30 \mathrm{~cm}$ & $0^{\circ}$ & Tidak Muncul Objek 3D & $\begin{array}{l}{[] \text { Diterima }} \\
{[\sqrt{]}] \text { Ditolak }}\end{array}$ \\
\hline 4. & Marker & $40 \mathrm{~cm}$ & $0^{\circ}$ & Tidak Muncul Objek 3D & $\begin{array}{l}{[] \text { Diterima }} \\
{[\sqrt{]} \text { Ditolak }}\end{array}$ \\
\hline 5. & Marker & $10 \mathrm{~cm}$ & $45^{\circ}$ & Muncul Objek 3D Hewan & $\begin{array}{l}{[\sqrt{]} \text { Diterima }} \\
{[\text { ] Ditolak }}\end{array}$ \\
\hline 6. & Marker & $20 \mathrm{~cm}$ & $45^{\circ}$ & Muncul Objek 3D Hewan & $\begin{array}{l}{[\sqrt{]} \text { Diterima }} \\
{[] \text { Ditolak }}\end{array}$ \\
\hline 7. & Marker & $30 \mathrm{~cm}$ & $45^{\circ}$ & Muncul Objek 3D Hewan & $\begin{array}{l}\text { [ ] Diterima } \\
{[\sqrt{]} \text { Ditolak }}\end{array}$ \\
\hline 8. & Marker & $40 \mathrm{~cm}$ & $45^{\circ}$ & Muncul Objek 3D Hewan & $\begin{array}{l}{[\mathrm{]} \text { Diterima }} \\
{[\sqrt{]}] \text { Ditolak }}\end{array}$ \\
\hline 9. & Marker & $10 \mathrm{~cm}$ & $90^{\circ}$ & Muncul Objek 3D Hewan & $\begin{array}{l}{[\sqrt{ }] \text { Diterima }} \\
\text { [ ] Ditolak }\end{array}$ \\
\hline 10. & Marker & $20 \mathrm{~cm}$ & $90^{\circ}$ & Muncul Objek 3D Hewan & $\begin{array}{l}{[\sqrt{]} \text { Diterima }} \\
{[] \text { Ditolak }}\end{array}$ \\
\hline 11. & Marker & $30 \mathrm{~cm}$ & $90^{\circ}$ & Muncul Objek 3D Hewan & $\begin{array}{l}\text { [ ] Diterima } \\
{[\sqrt{]}] \text { Ditolak }}\end{array}$ \\
\hline 12. & Marker & $40 \mathrm{~cm}$ & $90^{\circ}$ & Muncul Objek 3D Hewan & $\begin{array}{l}\text { [ ] Diterima } \\
{[\sqrt{]} \text { Ditolak }}\end{array}$ \\
\hline
\end{tabular}

Tabel 6. Pengujian Jarak dan Sudut marker $21 \times 30 \mathrm{~cm}$

\begin{tabular}{|c|c|c|c|c|c|}
\hline No & Data Masukan & Jarak & Sudut & Pengamatan & Hasil Pengujian \\
\hline 1. & Marker & $10 \mathrm{~cm}$ & $0^{\circ}$ & Tidak Muncul Objek 3D & $\begin{array}{l}{[] \text { Diterima }} \\
{[\sqrt{]} \text { Ditolak }}\end{array}$ \\
\hline 2. & Marker & $20 \mathrm{~cm}$ & $0^{\circ}$ & Tidak Muncul Objek 3D & $\begin{array}{l}{[] \text { Diterima }} \\
{[\sqrt{]} \text { Ditolak }}\end{array}$ \\
\hline 3. & Marker & $30 \mathrm{~cm}$ & $0^{\circ}$ & Tidak Muncul Objek 3D & $\begin{array}{l}{[] \text { Diterima }} \\
{[\sqrt{]}] \text { Ditolak }}\end{array}$ \\
\hline 4. & Marker & $40 \mathrm{~cm}$ & $0^{\circ}$ & Tidak Muncul Objek 3D & $\begin{array}{l}{[] \text { Diterima }} \\
{[\sqrt{]} \text { Ditolak }}\end{array}$ \\
\hline 5. & Marker & $50 \mathrm{~cm}$ & $0^{\circ}$ & Tidak Muncul Objek 3D & $\begin{array}{l}{[] \text { Diterima }} \\
{[\sqrt{]} \text { Ditolak }}\end{array}$ \\
\hline 6. & Marker & $60 \mathrm{~cm}$ & $0^{\circ}$ & Tidak Muncul Objek 3D & $\begin{array}{l}{[] \text { Diterima }} \\
{[\sqrt{ }] \text { Ditolak }}\end{array}$ \\
\hline 7. & Marker & $70 \mathrm{~cm}$ & $0^{\circ}$ & Tidak Muncul Objek 3D & $\begin{array}{l}{[] \text { Diterima }} \\
{[\sqrt{ }] \text { Ditolak }}\end{array}$ \\
\hline 8. & Marker & $10 \mathrm{~cm}$ & $45^{\circ}$ & Tidak Muncul Objek 3D & $\begin{array}{l}\text { [ ] Diterima } \\
{[\sqrt{ }] \text { Ditolak }}\end{array}$ \\
\hline 9. & Marker & $20 \mathrm{~cm}$ & $45^{\circ}$ & Tidak Muncul Objek 3D & $\begin{array}{l}{[\sqrt{ }] \text { Diterima }} \\
{[\text { ] Ditolak }}\end{array}$ \\
\hline 10. & Marker & $30 \mathrm{~cm}$ & $45^{\circ}$ & Muncul Objek 3D Hewan & $\begin{array}{l}{[\sqrt{]}] \text { Diterima }} \\
{[\text { ] Ditolak }}\end{array}$ \\
\hline 11. & Marker & $40 \mathrm{~cm}$ & $45^{\circ}$ & Muncul Objek 3D Hewan & $\begin{array}{l}{[\sqrt{]} \text { Diterima }} \\
{[\text { ] Ditolak }}\end{array}$ \\
\hline
\end{tabular}




\begin{tabular}{|c|c|c|c|c|c|}
\hline 12. & Marker & $50 \mathrm{~cm}$ & $45^{\circ}$ & Muncul Objek 3D Hewan & $\begin{array}{l}{[\sqrt{ }] \text { Diterima }} \\
{[\text { ] Ditolak }}\end{array}$ \\
\hline 13. & Marker & $60 \mathrm{~cm}$ & $45^{\circ}$ & Muncul Objek 3D Hewan & $\begin{array}{l}{[\sqrt{ }] \text { Diterima }} \\
\text { [ ] Ditolak }\end{array}$ \\
\hline 14. & Marker & $70 \mathrm{~cm}$ & $45^{\circ}$ & Tidak Muncul Objek 3D & $\begin{array}{l}\text { [ ] Diterima } \\
{[\sqrt{]} \text { Ditolak }}\end{array}$ \\
\hline 15. & Marker & $10 \mathrm{~cm}$ & $90^{\circ}$ & Tidak Muncul Objek 3D & $\begin{array}{l}\text { [ ] Diterima } \\
{[\sqrt{]} \text { Ditolak }}\end{array}$ \\
\hline 16. & Marker & $20 \mathrm{~cm}$ & $90^{\circ}$ & Tidak Muncul Objek 3D & $\begin{array}{l}{[] \text { Diterima }} \\
{[\sqrt{]} \text { Ditolak }}\end{array}$ \\
\hline 17. & Marker & $30 \mathrm{~cm}$ & $90^{\circ}$ & Muncul Objek 3D Hewan & $\begin{array}{l}\text { [ ] Diterima } \\
\text { [ } \sqrt{ } \text { ] Ditolak }\end{array}$ \\
\hline 18. & Marker & $40 \mathrm{~cm}$ & $90^{\circ}$ & Muncul Objek 3D Hewan & $\begin{array}{l}\text { [ }] \text { Diterima } \\
\text { [ ] Ditolak }\end{array}$ \\
\hline 19. & Marker & $50 \mathrm{~cm}$ & $90^{\circ}$ & Muncul Objek 3D Hewan & $\begin{array}{l}\text { [ }] \text { Diterima } \\
\text { [ ] Ditolak }\end{array}$ \\
\hline 20. & Marker & $60 \mathrm{~cm}$ & $90^{\circ}$ & Muncul Objek 3D Hewan & $\begin{array}{l}{[\sqrt{ }] \text { Diterima }} \\
\text { [ ] Ditolak }\end{array}$ \\
\hline 21. & Marker & $70 \mathrm{~cm}$ & $90^{\circ}$ & Tidak Muncul Objek 3D & $\begin{array}{l}\text { [ ] Diterima } \\
{[\sqrt{ }] \text { Ditolak }}\end{array}$ \\
\hline
\end{tabular}

\subsubsection{Pengujian Luas Permukaan (Occlusion)}

Pengujian untuk menentukan luas permukaan minimum dalam pelacakan image target pertama kali. Pengujian ini dilakukan dengan menghalangi area image target pada bagian tertentu pada empat sisi masing-masing seperti pada Gambar 9 dan 10.

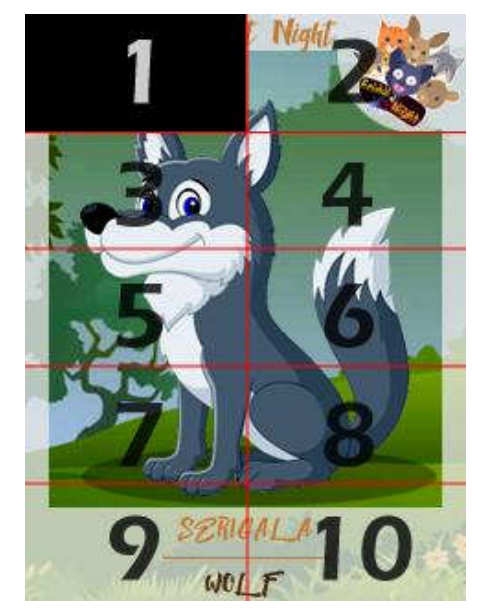

Gambar 9. Pengujian Menutup 10\% Image Target 


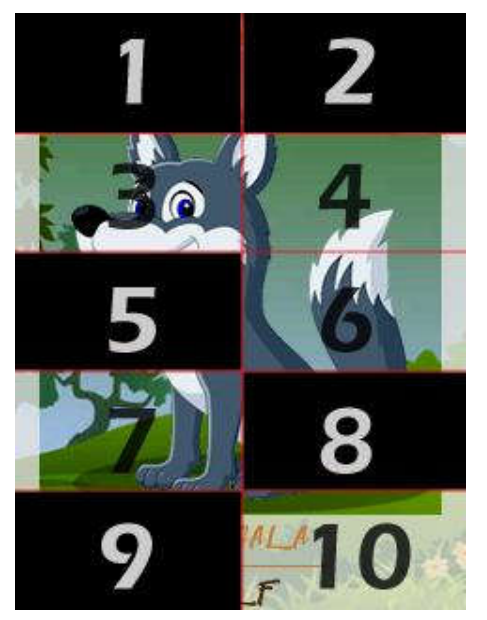

Gambar 10. Pengujian Menutup 50\% Image Target

Tabel 7. Hasil Pengujian occlusion

\begin{tabular}{|c|c|c|c|c|c|c|c|c|c|c|c|}
\hline \multirow[t]{2}{*}{$\%$ Occlusion } & \multicolumn{10}{|c|}{ No.Oclusion } & \multirow[t]{2}{*}{ HasilPengujian } \\
\hline & 1 & 2 & 3 & 4 & 5 & 6 & 7 & 8 & 9 & 10 & \\
\hline $10 \%$ & $\sqrt{ }$ & & & & & & & & & & [V ]Diterima [ ] Ditolak \\
\hline $20 \%$ & $\sqrt{ }$ & V & & & & & & & & & [V]Diterima [ ] Ditolak \\
\hline $30 \%$ & & & $\sqrt{ }$ & $\sqrt{ }$ & v & & & & & & [V ]Diterima [ ] Ditolak \\
\hline $40 \%$ & & & $\sqrt{ }$ & $\mathrm{v}$ & v & V & & & & & [ ]Diterima [V] Ditolak \\
\hline $50 \%$ & $\sqrt{ }$ & $\sqrt{ }$ & & & & & & $\mathrm{V}$ & $v$ & $\mathrm{~V}$ & [V] Diterima [ ]Ditolak \\
\hline $60 \%$ & V & $\mathrm{V}$ & $\sqrt{ }$ & $\sqrt{ }$ & & & & & 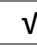 & $\mathrm{V}$ & [ ] Diterima [V]Ditolak \\
\hline $70 \%$ & $\mathrm{~V}$ & $\mathrm{~V}$ & 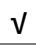 & $\sqrt{ }$ & 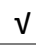 & $\sqrt{ }$ & $\sqrt{ }$ & & & & [ ] Diterima [V]Ditolak \\
\hline $80 \%$ & V & $\mathrm{V}$ & $\mathrm{V}$ & $\sqrt{ }$ & $\mathrm{V}$ & $\mathrm{V}$ & $\mathrm{V}$ & 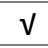 & & & [ ] Diterima [V]Ditolak \\
\hline $90 \%$ & V & V & V & $\sqrt{ }$ & $\sqrt{ }$ & $\checkmark$ & 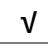 & $\sqrt{ }$ & $v$ & & [ ] Diterima [V]Ditolak \\
\hline $100 \%$ & V & V & $\sqrt{ }$ & $\sqrt{ }$ & V & $\mathrm{V}$ & V & $\mathrm{V}$ & $\mathrm{v}$ & V & [ ] Diterima [V ]Ditolak \\
\hline
\end{tabular}

\subsubsection{Kesimpulan hasil dan analisis}

Hasil analisis dari jarak, sudut dan occlusion adalah:

a. Jarak ideal posisi smartphone dengan marker ukuran $7 \times 10 \mathrm{~cm}$ adalah 10 sampai $20 \mathrm{~cm}$. Sedangkan jarak ideal untuk marker ukuran $21 \times 30 \mathrm{~cm}$ adalah 30 sampai $60 \mathrm{~cm}$. Maka semakin besar ukuran marker maka semakin jauh jarak ideal posisi smartphone dengan marker.

b. Sudut ideal pendeteksian dan pelacakan smartphone dengan image target adalah $45^{\circ}$ sampai $90^{\circ}$.

c. Image Target tidak dapat diidentifikasi oleh kamera jika persentase luas yang tidak terlihat (occlusion) adalah 50\% pada bagian 3,4,5 dan 6 dan 7. Area utama dalam pendeteksian marker adalah bagian $3,4,5,6,7$ dan 8 .

\section{SIMPULAN}

Berdasarkan hasil dari penelitian ini, didapatkan kesimpulan dari produk multimedia media pembelajaranpengenalanhewan berbasis augmented reality yaitu:

1. Rancang bangun media pembelajaran pengenalan hewan nokturnal berbasis android menggunakan augmented reality telah berhasil dilaksanakan dengan sampel data hewan: serigala, burung hantu, kelelawar, tikus, kecoa dan laba-laba,

2. Telah berhasil menerapkan virtual button pada single marker multi target aplikasi media pembelajaran pengenalan hewan nokturnal yang berfungsi untuk mengaktifkan fitur rotasi, zoom dan suara. 
3. Jarak ideal posisi smartphone dengan marker ukuran $7 \times 10 \mathrm{~cm}$ adalah 10 sampai $20 \mathrm{~cm}$. Sedangkan jarak ideal untuk marker ukuran $21 \times 30 \mathrm{~cm}$ adalah 30 sampai $60 \mathrm{~cm}$. Maka semakin besar ukuran marker maka semakin jauh jarak ideal posisi smartphone dengan marker.

4. Image Target dapat dengan mudah diidentifikasi oleh kamera jika persentase luas yang tidak terlihat (occlusion) adalah $60 \%$ baik pada pendeteksian maupun pada pelacakan.

5. Sudut ideal pendeteksian dan pelacakan smartphone dengan image target adalah $45^{\circ}$ sampai $90^{\circ}$.

6. Berdasarkan hasil kuesioner yang diberikan kepada 30 orang responden didapat total jumlah persentase jawaban "Ya" sebesar 77,8\%. Menurut tingkat validasi Slovin, aplikasi yang dibangun dinyatakan layak digunakan dengan interpretasi "Baik".

\section{SARAN}

Berikut adalah beberapa saran yang diharapkan mampu menambah penyempurnaan penelitian ini untuk produk multimedia media pembelajaran pengenalan hewan berbasis augmented reality $t$ yaitu:

1. Media pembelajaran perlu ditambahkan leaderboard untuk mengetahui prospek kemajuan user yang menggunakan.

2. Menambahkan level kesulitan dalam pengerjaan soal.

\section{DAFTAR PUSTAKA}

[1] Adam, S., Arie S. M. Lumenta, S. M., \& Jimmy R. Robot, S. M. (2014). Implementasi Teknologi Augmented Reality pada Agen Penjualan Rumah, E-journal Teknik Elektro dan Komputer, ISSN 2301-8402.

[2] Apriyani, M. E., \& Gustianto, R. (2015). Augmented Reality sebagai Alat Pengenalan Hewan Purbakala dengan Animasi 3D menggunakan Metode Single Marker, e-ISSN : 2460-0997.

[3] Apriansyah, A., Anugraha, D. M., Prakoso, G., Erdiham, K. N., \& Priyana, R. (2017). Aplikasi Pengenalan Hewan dengan Teknologi Marker Less Augmented Reality Berbasis Android. Journal of Computer and Information Technology E-ISSN: 2579-5317.

[4] Binanto, I. (2010). Multimedia Digital : Dasar Teori dan Pengembanganya. Yogyakarta: ANDI.

[5] Brata, K. C., Brata, A. H., \& Pramana, Y. A. (2017). Pengembangan Aplikasi Mobile Augmented Reality Untuk Mendukung Pengenalan Koleksi Museum , Jurnal Teknologi Informasi dan Ilmu Komputer (JTIIK).

[6] Ivanova, M., \& Ivanov, G. (2011). Enhancement of Learning and Teaching in Computer Graphics Through Marker Augmented Reality Technology. International Journal on New Computer Architectures and Their Applications (IJNCAA) 1(1): 176-184.

[7] Juan, M. C., \& Joele, D. (2011). A Comparative Study Of The Sense Of Presence And Anxiety In An Invisible Marker Versus A Marker Augmented Reality System For The Treatment Of Phobia Towards Small Animals. Int. J. Human-Computer Studies 69 440-453

[8] Lai, C.-L., \& Wang, C.-L. (2012 ). Mobile Edutainment with Interactive Augmented Reality Using Adaptive Marker Tracking. IEEE 18th International Conference on Parallel and Distributed Systems (ICPADS), 2012, pp. 124-131.

[9] Lee, K. (2012). Augmented Reality in Education and Training, TechTrends.

[10] LETRUD, K. (2012). A Rebuttal Of Ntl Institute'S Learning Pyramid. Education Vol. 133 No. 1.

[11] Luther, A. C. (1994). Authoring Interactive Multimedia.Boston : AP .

[12] P, M. (1996). . . Patty McCormick's Pieces of an American Quilt: Quilts, Patterns, Photos and Behind the Scenes Stories from the Movie,. Newyork: C \& T Publishing.

[13] Robin, \& Linda. (2001). Menguasai Pembuatan animasi dengan Macromedia Flash. Jakarta: Elek Media Komputindo.

[14] Roots, C. (2006). Nocturnal Animals (Greenwood Guides to the Animal World). Greenwood. 
[15] Sutopo. (2002). Multimedia Interaktif dengan Flash. Yogyakarta: Grha Ilmu.

[16] Turban. (2002). Aplikasi Multimedia Interaktif. Yogyakarta: Paradigma.

[17] Vaughan, T. (2011). Multimedia: Making It Work. 8th Edition. New York: McGraw-Hill. 